\title{
Species diversity and niche separation of cocoon parasitoids in different forest types with endemic populations of their host, the Common Pine Sawfly Diprion pini (Hymenoptera: Diprionidae)
}

\author{
ANNETTE HERZ* and WeRNER HEITLAND \\ Department of Ecology, Institute for Animal Ecology, Technische Universität München, Am Hochanger 13, \\ D-85354 Freising, Germany
}

\begin{abstract}
Key words. Community ecology, parasitoid diversity, outbreak, population dynamics, forest habitat, forest pest, pine sawfly
\end{abstract}
\begin{abstract}
Species diversity and potential impact of cocoon parasitoids on the abundance of the common pine sawfly, Diprion pini L. (Hymenoptera: Diprionidae), were explored in different forest habitats, with endemic sawfly populations, by the regular exposure of laboratory reared sawfly cocoons. Different cocoon spinning sites of the sawfly were simulated by exposing cocoons at several strata (soil, litter, trunk and stem of pine trees) in a forest. In more fertile, mixed spruce/pine-forests, parasitism on exposed cocoons was lower than in typical outbreak stands with a lower vegetational diversity. The parasitoid communities comprised of up to nine parasitoid species, which showed temporal and spatial niche separation. The ichneumonid Pleolophus basizonus Grav. (Hymenoptera: Phygadeuontinae) occured throughout the season at all strata as well as in all forest types. The ichneumonid Gelis cursitans F. (Hymenoptera: Phygadeuontinae) was only found in pine forests with sparsely developed ground vegetation, parasitizing exposed cocoons in the upper story in spring. The torymids Monodontomerus dentipes Dalm. (Hymenoptera: Torymidae) and M. minor Ratz. (Hymenoptera: Torymidae) were present in all forest types, but parasitized commonly only cocoons in the upper story in summer. Apparently, these generalists can quickly respond to increased densities of upper story exposed "summer" cocoons and thus limit the population growth of the pine sawfly due to the development of a second generation.
\end{abstract}

\section{INTRODUCTION}

Populations of forest pests often fluctuate, showing outbreaks and extended periods of low, endemic densities (Berryman et al., 1987). Parasitoids are generally considered to be key natural enemies determining these population dynamics (Kidd \& Jervis, 1997). On the other hand, it is suggested that strong fluctuations in host density may also create profound changes in the species composition of a parasitoid community due to the occurrence of high vs. low density specialists (Pschorn-Walcher, 1977; Mills, 1990; Hoch et al., 2001). Furthermore, varying environmental conditions may increase or restrict the abundance of parasitoid species by determining the presence or absence of other essential resources (Simmons et al., 1975; Roland et al., 1997; Lewis \& Whitfield, 1999; Quayle et al., 2003). Thus, the assemblage of parasitoids in a particular habitat will depend on host-related as well as environment-related factors and may result in a different degree of biological control of a pest (PschornWalcher, 1977; Mills, 1994).

The common pine sawfly, Diprion pini L. (Hymenoptera: Diprionidae) is a severe defoliator of pine forests all over Europe (Pschorn-Walcher, 1982) and is characterised by an eruptive outbreak pattern (Geri, 1988). Several decades ago, the parasitoid communities of this and other European pine sawflies were subjected to intensive research as part of a biological control programme
(Pschorn-Walcher, 1964; Ryvkin, 1969; Eichhorn \& Pschorn-Walcher, 1976; Eichhorn, 1981, 1982; Geri et al., 1986; Sharov, 1993). These studies were mainly conducted during outbreaks in Europe and it was shown that parasitoids significantly contributed to the collapse of the outbreaks (Eichhorn, 1981, 1982; Geri, 1988). However, the role of parasitoids during the periods of latency was unclear. Are they able to control any patches of higher host densities that arise? Is a failure of this function one factor favouring the development of an outbreak from "hot spots" of high pest density? In a study of the larval parasitoids of endemic populations of $D$. pini, we found a few highly specialized species, which could significantly limit the increase of sawfly populations, especially the tachinid Drino gilva Htg. (Herz \& Heitland, 1999).

Parasitoids attacking the cocoon stage of pine sawflies are mainly oligo- or even polyphagous species. Their impact during outbreaks of $D$. pini is well documented (Escherich, 1942; Pschorn-Walcher, 1982) but their species diversity and contribution to limit low density sawfly populations is less well known (Dusaussoy \& Geri, 1971; Eichhorn, 1995; Herz \& Heitland, 2003).

Outbreaks of pine sawflies were mainly observed in pine forests growing on degraded soils with a low vegetational diversity (Schwenke, 1962, 1964; Larsson \& Tenow, 1984). Several studies report a strong correlation between habitat conditions (especially forest fertility) and

* Corresponding and present address: Institute for Biological Control, Federal Research Centre for Agriculture and Forestry, Heinrichstr. 243, D-64287 Darmstadt, Germany; e-mail: A.Herz@bba.de 
the role of vertebrate predators in pine sawfly control (Hanski \& Parviainen, 1985; Hanski, 1987, 1990; Herz \& Heitland, 2003), which suggests natural enemies may make an important contribution to the sustainable prevention of outbreaks in forests on more fertile soils.

In some areas, where $D$. pini usually has only one generation per year, the build-up of populations was also correlated with the occurrence of bivoltine development, caused by favourable weather conditions in spring (Schwenke \& Steger, 1961; Ryvkin, 1963; Eichhorn, 1982, 1991). This suggests a potential failure of the limiting factors due to dissynchronization with the life cycle of the sawfly. One consequence of a bivoltine development in $D$. pini in these areas is the occurrence of "summer cocoons" which are usually attached to the twigs of the host trees or to shrubs and grasses closer to the forest floor. Currently little is known about the mortality of these summer cocoons during latency and its significance for further population growth (Eichhorn, 1995).

In a previous study, we compared the potential impact of cocoon predation and parasitism on endemic populations of $D$. pini in different forest types, with particular reference to cocoons in the soil and litter (Herz \& Heitland, 2003). In the present study, we evaluated the role of cocoon parasitoids in limiting the growth of sawfly populations by exploring species diversity and abundance of the parasitoids in relation to forest type and the spatial niches occupied by individuals of the two generations of the sawfly.

\section{MATERIAL AND METHODS}

\section{Study areas and field exposure of sawfly cocoons}

Sawfly cocoons were put out in the field in 1995 at two locations in Bavaria/Germany, situated at $400 \mathrm{~m}$ above sea level and exposed to similar macroclimatic conditions. Three experimental stands were located in an extended pine forest region around Nuremberg, which were representives of pure pine forests on sandy, nutrient-poor soils and where several outbreaks had occurred in the past ("poor pine forests": stands PP1, PP2, PP3, 100\% pine). In addition, neighbouring mixed spruce/pine forests were chosen as representives of non-susceptible forests where sawfly outbreaks have never been observed ("spruce/pine forests": stands SP1 and SP2, 70\% pine, 30\% spruce). Furthermore, a fertile pine stand that had no outbreak history was chosen in the vicinity of Munich ("rich pine forest": RP1, 100\% pine). All experimental stands were about 1 ha in size and embedded in similar forest. Tree age (70 to 90 years) and tree density (about 600 trees/ha) were comparable, but depended on forest type, with the trees clearly differing in productivity with the lowest growth classes in PP forests. Vegetational diversity depended on stand conditions. Between 27 and 40 different species of herbs, grasses and shrubs were found in the forests SP and RP. In contrast, the under story vegetation in the forests PP consisted of a fragmentary network of dwarf shrubs and a few other plant species, indicating nutrient-poor soil conditions and a water deficit (Herz, 1997).

In order to simulate the cocoon-spinning sites of the first and a second generation as well as that of diapausing stages, cocoons were exposed at different heights: soil (depth of 0.07 $\mathrm{m})$, litter (ground level), trunk ( $0.5 \mathrm{~m}$ above ground) and stem (3 $\mathrm{m}$ above ground). 40 pine trees were randomly chosen per stand and cages for the reception of cocoons were placed at the par- ticular heights (ten replicates/height). In general, cages (inner surface about $\left.400 \mathrm{~cm}^{2}\right)$ were constructed of metal gauze $(10 \mathrm{~mm}$ mesh), which enclosed the cocoons but allowed parasitoids to enter [for detailed description see Herz (1997)]. A group of ten cocoons (both sexes, randomly mixed) was placed in each cage and exchanged every six weeks throughout the experimental period. Cocoons buried in the soil were put in the cage, which was then covered by a layer (c.a. $7 \mathrm{~cm}$ depth) of soil and litter. Cocoons deposited in the litter in a cage were covered by a thin layer of litter (c.a. 0.5 to $1 \mathrm{~cm}$ ). Cocoons placed on trunks and stems, respectively, were glued into pine bark crevices with a non-toxic glue and then covered with a metal cage. The exposure periods at Nuremberg were: $28^{\text {th }}$ April $-10^{\text {th }}$ June (spring), $10^{\text {th }}$ June $-24^{\text {th }}$ July (early summer), $24^{\text {th }}$ July $-14^{\text {th }}$ September (late summer), $14^{\text {th }}$ September $-28^{\text {th }}$ October (fall) and at Munich: $5^{\text {th }}$ May $-19^{\text {th }}$ June (spring), $19^{\text {th }}$ June $-1^{\text {st }}$ August (early summer), $1^{\text {st }}$ August $-22^{\text {nd }}$ September (late summer), $22^{\text {nd }}$ September $-6^{\text {th }}$ November (autumn). A permanent rearing of $D$. pini in the laboratory ensured a sufficient supply of sawfly cocoons for the field trials (Herz, 1997). Only cocoons of larvae that had been reared under short-day conditions to induce diapause (Eichhorn, 1976) were used, thus preventing the emergence of adult sawflies in the field.

\section{Species determination and efficacy of cocoon parasitoids}

After each period of exposure, cocoons were returned to the laboratory and were at first classified as open due to predators, parasitoids or the sawfly itself (Escherisch, 1942) or intact. Intact cocoons were opened by cutting them in half and the contents examined for the presence of parasitoids. Parasitoids of sawfly cocoons are ectoparasitic idiobionts and their eggs, larvae and pupae were reared by enclosing the cocoon with the host eonymph after dissection and incubating them under long day conditions in a climatic chamber $\left(20^{\circ} \mathrm{C}, 70 \%\right.$ r.H. $)$. The parasitoids that emerged were identified using the keys of Askew (1968), Ferrière \& Kerrich (1958), Fitton et al. (1988), Nikolskaya (1952), Oehlke (1966), Perkins (1959, 1960), Sellenschlo \& Wall (1984) and Richards (1956). Voucher specimen of the different Ichneumonidae were identified by D.R. Kasparyan, University of Petersburg and M. Schwartz, University of Salzburg and those of the Chalcidoidae by S. Vidal, University of Göttingen. Adults of all the parasitoids reared are in the entomological collection of the Institute of Animal Ecology (TU Munich) in Freising.

Effective parasitism was calculated by relating the number of parasitized cocoons to the number of cocoons initially exposed. Predation of the exposed cocoons was generally low $(<15 \%)$ in poor pine forests, but significant in the fertile forest in late summer and fall. This predation was probably due to shrews, because most of the cocoons were removed. According to Buckner (1958) and Holling (1955, 1958), parasitized cocoons are not eaten by these predators, so we assumed that the parasitized cocoons were left. To avoid any overestimation of parasitoid attack, we did not calculate parasitism rates on the basis of retrieved cocoons, but on the number of exposed cocoons. Some parasitoid attacks resulted in multi- or superparasitism. The attack rate was calculated by relating the total number of parasitoid attacks to the initial number of cocoons.

Relative abundance (\%) of a particular parasitoid species was calculated by relating the number of attacks by this species to the total number of parasitoid attacks.

\section{Species diversity and niche separation}

Species diversity was calculated using the Shannon-Index $H^{\prime}$ (Magurran, 1988):

$$
H^{\prime}=\Sigma p_{i} \ln p_{i}
$$


where $p_{i}=n_{i} / \mathrm{N}$ and number of individuals of species $i\left(n_{i}\right)$ divided by the total number of parasitoid individuals $(\mathrm{N})$ in the sample. Increasing values of $H^{\prime}$ indicate increasing species diversity.

The species composition of two experimental stands was compared by calculating the Morista-Horn-Index $C_{m H}$, which takes into account both species richness and abundance of the individual species within a particular community (Magurran, 1988).

$$
C_{m H}=\left[2 \Sigma\left(n_{i \mathrm{a}} n_{i \mathrm{~b}}\right)\right] /\left[\left(d_{\mathrm{a}}+d_{\mathrm{b}}\right) N_{\mathrm{a}} N_{\mathrm{b}}\right]
$$

where $N_{\mathrm{a}} ; N_{\mathrm{b}}=$ total number of individuals on plot $\mathrm{A}$ and $\mathrm{B}$, respectively; $n_{i \mathrm{a}} ; n_{i \mathrm{~b}}=$ number of individuals of particular species $i$ on plot A and $\mathrm{B}$, respectively; $d_{\mathrm{a}}=\sum n_{i \mathrm{a}}{ }^{2} / N_{\mathrm{a}}{ }^{2}$ and $d_{\mathrm{b}}=\Sigma$ $n_{\mathrm{bb}}{ }^{2} / N_{\mathrm{b}}{ }^{2}$. Increasing values of $C_{m H}$ indicate increasing similarity between two plots, with a maximum of 1 ( $100 \%$ of similarity).

Niche separation among species was estimated by testing the influence of different spatial and temporal factors on the attack rate of key species. Species-specific exploitation of host resources was examined by comparing cocoon exploitation, variation in clutch size and sex allocation between key parasitoid species. Statistical analysis was performed using the statistical software program GLIM $^{\odot}$ (NAG Software). Results were arcsine- or square-root-transformed before using General Linear Models with normal error distribution. Counts and frequencies (number of cocoons/patch exploited, sex ratio) were analyzed by using General Linear Models with Poisson error distribution and log link. Overdispersion of data was corrected using Pearson's $\chi^{2}$ and data sets were analyzed by ANOVA or G-Test of independence (Crawley, 1993).

\section{RESULTS}

\section{Species composition of the parasitoid community in different forest types}

The parasitoids were identified to species for $82 \%$ of the attacked cocoons. Another $15 \%$ were identified to the superfamily (Ichneumonoidea or Chalcidoidea). The exposed cocoons were parasitized by nine different parasitoid species (Table 1). Four species belong to the superfamily Chalcidoidea: Tritneptis klugi Ratz. (Pteromalidae), Dahlbominus fuscipennis Zett. (Eulophidae), Monodontomerus minor Ratz., and Monodontomerus dentipes Dalm. (Torymidae). Ichneumonidae were represented by Gelis cursitans Fabr., Pleolophus basizonus Grav., Aptesis pugnax Hart., Agrothereutes adustus Grav. (all Phygadeuontinae) and Delomerista pfankuchi Först. (Pimplinae).

In general, the species diversity of cocoon parasitoids, estimated by the Shannon-Index, was higher in the "poor pine forests" (Table 2). With increasing species diversity, there was an increase in overall parasitism from very low levels in the mixed spruce/pine forests to $21 \%$ in stand PP1. The composition and structure of the parasitoid community was similar in the PP-forests ( $>90 \%$ similarity as measured by the Morista-Horn-Index) on the one hand and in the more fertile forests (SP, RP) on the other (Table 3 ). The relative abundance of the different parasitoid species depended on general forest structure (Table 1). Three species were found in all forest stands: M. dentipes, M. minor and P. basizonus. M. dentipes was the dominant species. The ichneumonid $G$. cursitans made up $20 \%$ of the parasitoids in the poor pine forests, but rarely
TABLE 1. Species composition of parasitoids recorded from exposed cocoons of $D$. pini in different forest habitats. Abundance of a particular species is expressed as a percentage of total number of parasitoids. SP: Spruce/Pine-forest, RP: Rich Pine forest, PP: Poor Pine forest. —: no record. Data of all exposures combined.

\begin{tabular}{|c|c|c|c|c|c|c|}
\hline & \multicolumn{6}{|c|}{$\begin{array}{c}\text { Relative abundance (\%) } \\
\text { of species at stand }\end{array}$} \\
\hline & SP1 & SP2 & RP1 & PP1 & PP2 & PP3 \\
\hline \multicolumn{7}{|l|}{ Chalcidoidea } \\
\hline Monodontomerus dentipes & 78 & 61 & 60 & 38 & 39 & 36 \\
\hline Monodontomerus minor & 4 & 19 & 5 & 2 & 11 & 2 \\
\hline Dahlbominus fuscipennis & - & - & - & 2 & - & 1 \\
\hline Tritneptis klugi & - & - & 1 & - & - & $<1$ \\
\hline unidentified $*$ & 3 & - & 1 & 4 & 5 & 5 \\
\hline \multicolumn{7}{|l|}{ Ichneumonoidea } \\
\hline Pleolophus basizonus & 13 & 3 & 19 & 19 & 6 & 12 \\
\hline Gelis cursitans & - & - & $<1$ & 17 & 20 & 26 \\
\hline Delomerista pfankuchi & - & 11 & 4 & - & - & - \\
\hline Aptesis pugnax & 1 & - & - & 4 & - & 2 \\
\hline Agrothereutes adustus & - & - & $<1$ & - & - & 1 \\
\hline unidentified* & 1 & 6 & 10 & 12 & 15 & 15 \\
\hline
\end{tabular}

*No adult parasitoids were obtained, classification based on emergence holes/larval rudiments.

occured in the more fertile stands. The other species were found only sporadically.

\section{Impact of cocoon parasitoids}

The level of parasitism of the exposed cocoons varied not only between the different forest types, but also between the cocoon spinning sites and seasons (Fig. 1). In most cases, parasitism of soil and litter cocoons did not exceed $10 \%$ from spring to fall in all forest stands. As reported elsewhere (Herz \& Heitland, 2003), a high predation of soil and litter cocoons was recorded in the more fertile forest stands, which may have interfered with cocoon parasitism. Much higher levels of parasitism were recorded for cocoons situated above ground at particular periods of the year. More than $50 \%$ of the cocoons on stems were parasitized in all forest stands in late summer. Cocoons placed on the trunks in the pine forests (PP and RP) also suffered significantly higher levels of parasitism.

TABLE 2. Parasitism (\%) and species diversity of the parasitoids of cocoons of $D$. pini exposed in different forest habitats. Species diversity was calculated using the Shannon-Index. SP: Spruce/Pine forest, RP: Rich Pine forest, PP: Poor Pine forest. Data of all exposures combined.

\begin{tabular}{lcccccc}
\hline & SP1 & SP2 & RP1 & PP1 & PP2 & PP3 \\
\hline S cocoons exposed & 1504 & 1575 & 1582 & 1586 & 1561 & 1543 \\
S parasitoid attacks & 80 & 70 & 253 & 345 & 314 & 282 \\
Effective parasitism* (\%) & 5.3 & 3.9 & 14.9 & 20.8 & 17.4 & 16.5 \\
Species diversity & 0.62 & 0.96 & 0.97 & 1.36 & 1.17 & 1.32 \\
\hline
\end{tabular}

* number of parasitized cocoons/number of exposed cocoons 
TABLE 3. Similarity in the diversity and proportional distribution of cocoon parasitoids in different forest habitats estimated using the Morista-Horn-Index. SP: Spruce/Pine forest, RP: Rich Pine forest, PP: Poor Pine forest.

\begin{tabular}{cccccc}
\hline & SP1 & SP2 & RP1 & PP1 & PP2 \\
\hline SP2 & $\mathbf{0 . 9 6 6}$ & - & - & - & - \\
RP1 & $\mathbf{0 . 9 7 6}$ & $\mathbf{0 . 9 5 2}$ & - & - & - \\
PP1 & 0.749 & 0.787 & 0.886 & - & - \\
PP2 & 0.828 & 0.861 & 0.856 & $\mathbf{0 . 9 2 5}$ & - \\
PP3 & 0.760 & 0.747 & 0.806 & $\mathbf{0 . 9 6 5}$ & $\mathbf{0 . 9 5 7}$ \\
\hline
\end{tabular}

\section{Niche separation of the key species}

The spatial and temporal pattern in parasitism in the different forest stands was mainly associated with the different activity ranges of the most abundant parasitoids $M$. dentipes, M. minor, G. cursitans and P. basizonus (Table 4). G. cursitans mainly parasitized cocoons placed on trunks and stems of trees in spring and early summer. $P$. basizonus was the only parasitoid active in all strata and throughout the whole experimental period, but most consistantly so in the soil and litter. In contrast, the Monodontomerus-species only parasitized cocoons placed on trunks and stems, indicating that these parasitoids searched and attacked hosts only in the upper story of forests. They were abundant in all forest types (Table 1), but mainly in early and late summer. $M$. dentipes was the most effective parasitoid, parasitising more than $50 \%$ of the cocoons. The influence of forest type, season and stratum on the attack rates of the different key species were analyzed separately using factorial ANOVA (Table 5). The attack rates of both Monodontomerus species were significantly affected by season and stratum but not forest type. The attack rate of G. cursitans varied signifi-

TABLE 4. Attack rate $(\%$, mean $\pm \mathrm{SD})$ of the different parasitoid species measured by placing cocoons of $D$. pini in the soil and litter and on trunks and stems of trees at different periods of a year in pine forest stands (PP1, PP2, PP3) in 1995.

\begin{tabular}{|c|c|c|c|c|c|}
\hline & & M. dentipes & M. minor & G. cursitans & P. basizonus \\
\hline \multirow{4}{*}{ Spring } & soil & - & - & - & $4.3 \pm 4.5$ \\
\hline & litter & - & - & - & $1.7 \pm 2.9$ \\
\hline & trunk & - & - & $27.8 \pm 8.2$ & - \\
\hline & stem & $2.7 \pm 4.6$ & $0.3 \pm 0.6$ & $10.1 \pm 4.5$ & - \\
\hline \multirow{4}{*}{$\begin{array}{l}\text { Early } \\
\text { summer }\end{array}$} & soil & - & - & - & $1.3 \pm 2.3$ \\
\hline & litter & - & - & - & $1.0 \pm 1.0$ \\
\hline & trunk & $4.3 \pm 4.9$ & $0.7 \pm 0.1$ & $20.8 \pm 4.3$ & - \\
\hline & stem & $4.2 \pm 4.2$ & $1.7 \pm 2.0$ & $6.6 \pm 3.1$ & - \\
\hline \multirow{4}{*}{$\begin{array}{l}\text { Late } \\
\text { summer }\end{array}$} & soil & - & - & $0.4 \pm 0.6$ & $1.7 \pm 2.9$ \\
\hline & litter & $0.3 \pm 0.6$ & - & - & $8.0 \pm 1.7$ \\
\hline & trunk & $50.8 \pm 11.1$ & $7.7 \pm 10.7$ & $1.0 \pm 1.0$ & $0.3 \pm 0.6$ \\
\hline & stem & $57.9 \pm 5.6$ & $6.1 \pm 2.5$ & $1.7 \pm 1.1$ & - \\
\hline \multirow{4}{*}{ Fall } & soil & - & - & - & $1.6 \pm 2.8$ \\
\hline & litter & - & - & - & $6.0 \pm 4.6$ \\
\hline & trunk & - & - & - & $10.3 \pm 4.0$ \\
\hline & stem & $0.03 \pm 0.06$ & - & - & $3.3 \pm 4.8$ \\
\hline
\end{tabular}
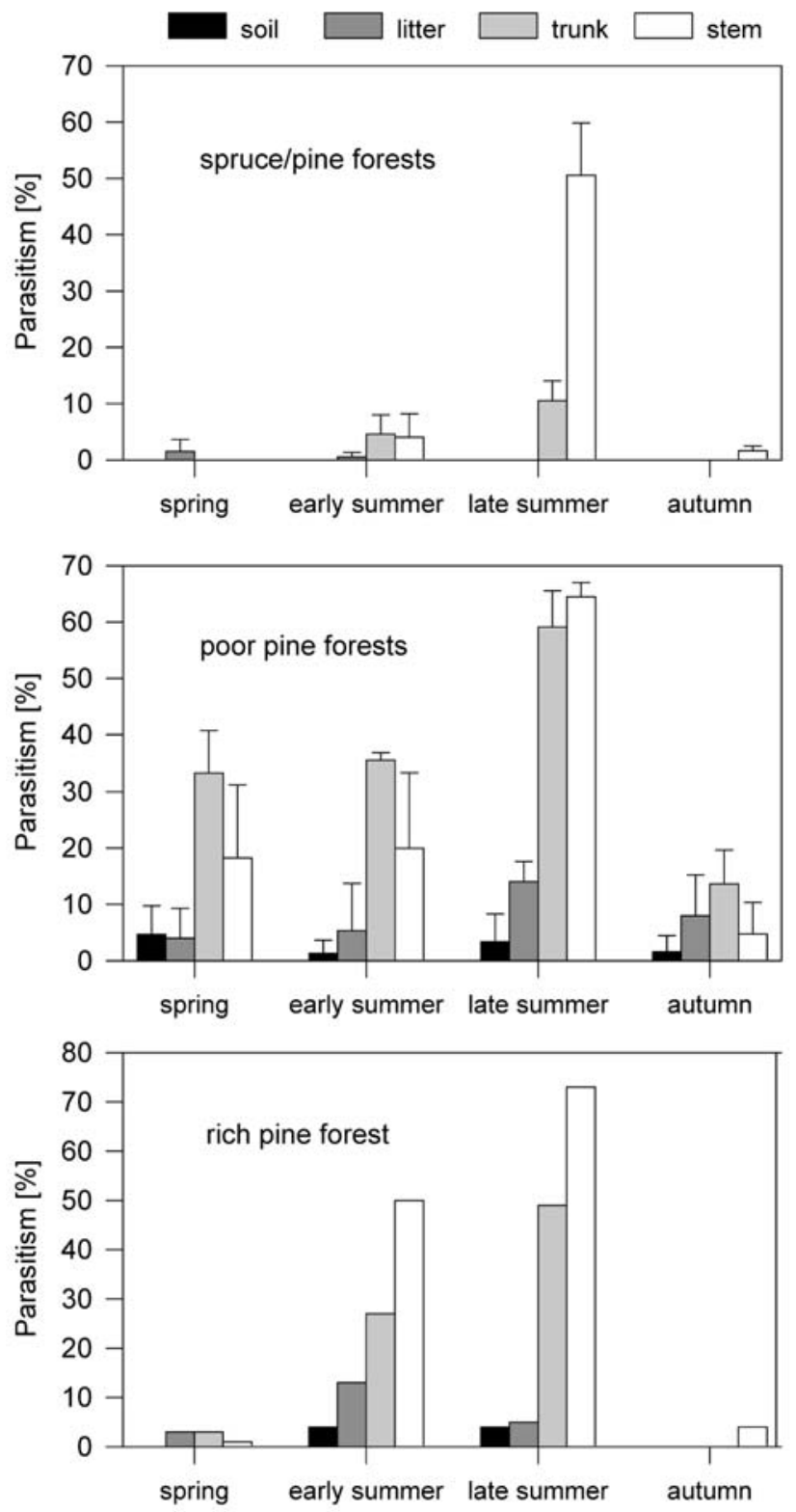

Fig. 1. Parasitism (\%) of D. pini-cocoons exposed at particular times of a year (spring, early summer, late summer, autumn) in the soil and litter and on the trunks and stems of trees in different forest types. For each period, about 100 cocoons were placed in each place. Values are means \pm SD for the cocoons exposed in several stands except in the case of the rich pine forest, where only one stand was sampled.

cantly with season, stratum and forest, whereas that of $P$. basizonus was independent of season, suggesting that this species is active throughout the season.

Cocoons were exposed in patches of ten, which in most cases were not completely exploited by the parasitoids, even if suitable hosts were still availabe (on average 2.4 cocoons/patch). Male and female sawfly cocoons differ in size due to the shorter development of male larvae (Escherich, 1942). The gregarious M. dentipes laid significantly more eggs in the larger cocoons of female pine sawflies $(\mathrm{F}=83.9, P<0.01)$, whereas the progeny of the solitary ichneumonid species G. cursitans and P. basi- 
TABLE 5. Effect of environmental factors on the attack rate of the different parasitoids of $D$. pini cocoons. Transformed data were analyzed using General Linear Models and factorial ANOVA. Only significant factors were kept in the GLM. Var: deviance, d.f.: degrees of freedom. $*: \mathrm{P}<0.05, * *: \mathrm{P}<0.01, * * *: \mathrm{P}<0.001$, ns: not significant.

\begin{tabular}{|c|c|c|c|c|c|c|c|c|c|}
\hline & \multirow[b]{2}{*}{ d.f. } & \multicolumn{2}{|c|}{ M. dentipes } & \multicolumn{2}{|c|}{ M. minor } & \multicolumn{2}{|c|}{ G. cursitans } & \multicolumn{2}{|c|}{ P. basizonus } \\
\hline & & Var & $\mathrm{F}$ & Var & $\mathrm{F}$ & Var & $\mathrm{F}$ & Var & $\mathrm{F}$ \\
\hline Total & 95 & 6.35 & & 0.69 & & 1.90 & & 1.33 & \\
\hline Season & 3 & 1.91 & $12.1 * *$ & 0.18 & $9.5^{* *}$ & 0.19 & $5.4^{* *}$ & ns & \\
\hline Forest & 2 & ns & & ns & & 0.31 & $12.7 * *$ & 0.14 & $5.9 * *$ \\
\hline Stratum & 3 & 1.47 & $10.2 * *$ & 0.12 & $7.5^{* *}$ & 0.34 & $9.4 * *$ & 0.13 & $3.6^{*}$ \\
\hline Error & & 2.96 & & 0.39 & & 1.05 & & 1.06 & \\
\hline
\end{tabular}

zonus that laid eggs in those cocoons developed into female progeny (Table 6; G-Test of independence (Crawley, 1993): G. cursitans: $\chi^{2}=4.56, P<0.05 ; P$. basizonus: $\left.\chi^{2}=6.47, P<0.05\right)$.

\section{DISCUSSION AND CONCLUSIONS}

Vegetational diversity and higher diversification in forest- or agroecosystems are assumed to enhance the activity of natural enemies and thereby contribute to a better control of pests (Russell, 1989). In our study, vegetational diversity was higher in the spruce/pine-forest stands and RP-plot than in the "poor pine" forests. However, the species diversity of parasitoids, as well as effective parasitism, was highest in the "poor pine" stands. These stands are the preferred habitat of pine sawflies and the population densities there are probably significant even during the latent periods (Herz \& Heitland, 2000). With the exception of the Monodontomerus-species, we mainly recorded oligophagous parasitoids, which specialize on diprionid sawflies (Pschorn-Walcher, 1982). Apparently, as specialists, they depend on the sustainable occurrence of their primary hosts and may require similar habitat conditions. As proposed by Sheehan (1986), specialist natural enemies are probably favoured in less diverse environments, which allow more efficient foraging for their particular hosts. The less complex ground flora in PP-stands may facilitate host location by littersearching parasitoids such as $P$. basizonus. But is it possible to promote these parasitoids and increase their contribution to the sustainable control of sawflies? A better means of conserving this type of specialized parasitoid may be to stabilize densities of economically insignificant pine sawflies (e.g. several species of the genus Gilpinia) in forests by increasing their structural diversity. For instance, increasing the range of ages of trees in pine forests may favour a more stable pine sawfly community as the different sawfly species prefer particular age classes of pine (Pschorn-Walcher, 1982). The effect of introducing additional food resources on abundance and diversity of these parasitoids into a typical pine forest also remains to be determined. For instance, Cappuccino et al. (1999) found that the application of sucrose enhanced the number of parasitoids attacking the larvae of Choristoneura fumiferana. Our survey had to be restricted to a low number of experimental stands per forest type, thus limiting the generality of the conclusions on the relation between forest and parasitoid diversity. Further manipulative experiments are required to determine the kinds of diversity (vegetation, host \& food resources, general habitat structure?) that are important determinants of abundance and function of host specific parasitoids in the forest ecosystem.

Monodontomerus-species accounted for most of the parasitism in SP-forests, reaching rates of parasitism comparable to those recorded in PP plots. Within the parasitoid complex of D. pini recorded in this study, Monodontomerus species were the least specific, parasitizing pine and spruce sawflies, and species of Lepidoptera (Sellenschlo \& Wall, 1984). Moreover, they also tended to superparasitism, attacking previously parasitized cocoons. Their polyphagy may enable them to sustain higher densities in all forest types and show an immediate functional response to growing sawfly populations. This finding suggests that the polyphagous Monodontomerus-species are favoured by diverse habitats in which there is a greater availability of alternative hosts, which - for instance - develop on spruce. Though spatially and temporally restricted, they parasitized a high proportion of

TABLE 6. Host exploitation by the parasitoids of D. pini cocoons measured in terms of the parasitized hosts per patch and number or sex of progeny in relation to male and female hosts. Values are mean \pm SD.

\begin{tabular}{|c|c|c|c|c|}
\hline & M. dentipes & M. minor & G. cursitans & P. basizonus \\
\hline n of attacked patches & 129 & 47 & 76 & 97 \\
\hline $\begin{array}{l}\mathrm{n} \text { parasitized cocoons } / \text { patch }^{1} \\
\mathrm{n} \text { progeny/cocoon }\end{array}$ & $4.79 \pm 0.24^{\mathrm{a}}$ & $1.70 \pm 0.15^{\mathrm{b}}$ & $2.61 \pm 0.21^{\mathrm{c}}$ & $2.24 \pm 0.18^{\mathrm{c}}$ \\
\hline Male host & $1.46 \pm 0.09$ & $1.31 \pm 0.24$ & 1.05 & 1 \\
\hline $\begin{array}{l}\text { Female host } \\
(\%) \text { of female/progeny }\end{array}$ & $6.40 \pm 0.21$ & $2.67 \pm 0.67$ & 1 & 1 \\
\hline Male host & 81 & 68 & 82 & 60 \\
\hline Female host & 82 & 68 & 97 & 79 \\
\hline
\end{tabular}

${ }^{1}$ One patch consisted of 10 cocoons. Different letters indicate significant differences $(P<0.01)$. Data for all exposures combined. 
above-ground cocoons in summer, indicating that Monodontomerus may be able to limit the population growth of sawflies that results from a bivoltine development. Hoch et al. (2001) observed a rapid reaction of the parasitoid Glyptapanteles liparidis to artificially increased populations of Lymantria dispar. Such spatial and/or temporal density-dependent responses of natural enemies may prevent the development of outbreaks from "hot spots" of increased herbivore density.

In addition to the spatial differences in parasitism by the key species $M$. dentipes, G. cursitans and P. basizo$n u s$, they also showed differences in host exploitation. On average, the ichneumonids parasitized less than three cocoons per patch, although suitable hosts were still available. P. basizonus is a synovigenous species (Griffiths, 1969). Host location is associated with marking hosts and locations by odour trails (Price, 1969, 1972). These traits may account for short patch residence time, an adaptation to a spatially scattered hosts, resulting in a high searching efficiency at low host densities. The biology of $G$. cursitans is unknown, but the searching efficiency of this apterous species must be quite high, as it accounted for high levels of parasitism in the present study. In the literature, Gelis species are often mentioned as hyperparasitoids of sawflies (Pschorn-Walcher, 1982), but $G$. cursitans was mainly a primary parasitoid in this study. The parasitoids were also able to assess the quality (= size) of their hosts and alter the number (gregarious species: M. dentipes) and sex (solitarious species: G. cursitans, $P$. basizonus) of their progeny accordingly, which resulted in their progeny being strongly female-biased (Hassell \& Waage, 1984; Charnov, 1982).

Species diversity of parasitoid communities was higher during outbreaks of $D$. pini in Northern and Southwest Germany than in the present study (Eichhorn, 1981, 1983, 1995). The abundance of the species was also different: $M$. dentipes was quite rare and cocoons in upper story vegetation were mainly parasitized by $A$. adustus. Both $A$. pugnax and D. fuscipennis were common, unlike this study. The ichneumonid P. basizonus was also the most regularly recorded parasitoid in these surveys. As stated before, the species composition of a parasitoid community may depend on abundance of the host insect (Pschorn-Walcher, 1977; Mills, 1990, 1994). Eichhorn (1995) observed changes in species composition in the years following a $D$. pini-outbreak: the parasitoids $A$. adustus and $D$. fuscipennis declined but $M$. dentipes became more abundant. Thus, those and the results of our study indicate that the generalist $M$. dentipes is most important when the host density is low. But in the complex forest habitat, parasitoid activity could be affected by stand composition, the occurrence of alternate hosts and year-to-year variation in weather conditions, as recently demonstrated for the parasitism of spruce budworm eggs by Trichogramma minutum (Quayle et al., 2003). Therefore, in order to obtain a more complete picture of lowdensity parasitoid communities of pine sawflies and other forest pests, long-term investigations need to take these factors into account.
ACKNOWLEDGEMENTS. This study was supported by the Bavarian Ministry of Agriculture and Forestry (STELF) and the Arthur \& Aenne Feindt-Stiftung, Hamburg. Special thanks are extended to the foresters Mr. Riedlbauch and Mr. Schellartz for help during fieldwork and J. Brummer, F. Scheyhing and S.C. Görken for technical assistance. We would like to thank also D.R. Kasparyan, M. Schwartz and S. Vidal for identifying the parasitoids.

\section{REFERENCES}

AsKew R.R. 1968: Handbooks for the Identification of British Insects. Vol VIII, Part 2(b). Chalcidoidea. Royal Entomological Society of London, London, $39 \mathrm{pp}$.

Berryman A.A., Stenseth N.C. \& Isaev A.S. 1987: Natural regulation of herbivorous forest insect populations. Oecologia 71: 174-184.

BUCKNER C.H. 1958: Mammalian predators of the Larch sawfly in Eastern Manitoba. Proceedings $10^{\text {th }}$ International Congress of Entomology, Montreal 1956. pp. 353-362.

Crawley M.J. 1993: GLIM for Ecologists. Blackwell Scientific Publications, Oxford, UK, $379 \mathrm{pp}$.

Cappuccino N., Houle M.J. \& Stein J. 1999: The influence of understory nectar resources on parasitism of the spruce budworm Choristoneura fumiferana in the field. Agric. Forest Entomol. 1: 33-36.

Charnov E. 1982: The Theory of Sex Allocation. Monographs in Population Biology 18. Princeton University Press, Princeton, USA, $355 \mathrm{pp}$.

Dusaussoy G. \& GerI C. 1971: Etude des populations résiduelles de Diprion pini après la gradation de 1963-1964. Ann. Sci. Forest. 28: 297-322.

EichHoRn O. 1976: Dauerzucht von Diprion pini L. (Hym.: Diprionidae) im Laboratorium unter Berücksichtigung der Fotoperiode. Anz. Schädlingsk. Pflschutz Umweltschutz 49: $38-41$.

EICHHORN O. 1981: Autökologische Untersuchungen an Populationen der Gemeinen Kiefernbuschhornblattwespe Diprion pini (L.) (Hym., Diprionidae). VI. Zur Kenntnis der Kokonparasiten und Exenterus- Arten. Z. Angew. Entomol. 92: 252-285.

EICHHORN O. 1982: Untersuchungen zur Ökologie der Gemeinen Kiefern-Buschhornblattwespe, Diprion pini (L.) (Hym., Diprionidae). VII. Populationsdynamische Faktoren. Z. Angew. Entomol. 94: 271-300.

EICHHORN O. 1983: Untersuchungen zur Ökologie der Gemeinen Kiefernbuschhornblattwespe, Diprion pini (L.) (Hym., Diprionidae). VIII. Verlauf der Massenvermehrung bei Speyer (Pfalz) 1976-1978. Z. Angew. Entomol. 96: 291-303.

EICHноRN O. 1991: Voltinismus und Schlüpfwellenfolge mitteleuropäischer Ökotypen der Kiefern-Buschhornblattwespe Diprion pini L. (Hym., Diprionidae), ihre Mechanismen und ihre Bedeutung für den Massenwechsel. J. Appl. Entomol. 112: $437-453$

EICHHORN O. 1995: Entwicklungs- und Parasitierungsverlauf der Gemeinen Kiefernbuschhornblattwespe, Diprion pini (L.) (Hym., Diprionidae) im Gradationsgebiet bei Speyer während der Latenzphase 1979-1984. Waldhygiene 20: 193-207.

EichHorn O. \& Pschorn-Walcher H. 1976: Studies on the biology and ecology of the egg-parasites (Hym.: Chalcidoidea) of the pine sawfly Diprion pini (L.) (Hym.: Diprionidae) in Central Europe. Z. Angew. Entomol. 80: 355-381.

Escherich E. 1942: Die Forstinsekten Mitteleuropas. Vol. V. Paul Parey, Berlin, Germany, 746 pp. 
FerRIÈRe C. \& KerRICH G.J. 1958: Handbooks for the Identification of British Insects. Vol VIII, Part 2(a). Chalcidoidea. Royal Entomological Society of London, London, $40 \mathrm{pp}$.

FitTon M.G., Shaw M.R. \& Gauld I.D. 1988: Handbooks for the Identification of British Insects. Vol VII, Part 1. Ichneumonidae - Pimplinae. Royal Entomological Society of London, London, $110 \mathrm{pp}$.

Geri C. 1988: The pine sawfly in central France. In Berryman A.A. (ed): Dynamics of Forest Insect Populations. Patterns, causes, Implications. Plenum Press, New York, pp. 377-405.

Geri C., Goussard F. \& Reveillon M. 1986: Reflexion sur l'utilisation des auxiliares entomophages contre Diprion pini (Hym. Diprionidae). Entomophaga 31: 27-38.

Griffiths K.J. 1969: Development and diapause in Pleolophus basizonus (Hymenoptera: Ichneumonidae). Can. Entomol. 101: 907-914.

HANSKI I. 1987: Pine sawfly population dynamics: pattern, processes, problems. Oikos 50: 327-335.

HANSKI I. 1990: Small mammal predation and the population dynamics of Neodiprion sertifer. In Watt A.D., Leather S.R., Hunter M.D. \& Kidd N.A.C. (eds): Population Dynamics of Forest Insects. Intercept, Andover, pp. 253-263.

Hanski I. \& Parviainen P. 1985: Cocoon predation by small mammals, and pine sawfly population dynamics. Oikos 45 : $125-136$.

Hassell M.P. \& WaAge J.K. 1984: Host-parasitoid population interactions. Ann. Rev. Entomol. 29: 89-114.

Herz A. 1997: Zur Effektivität und Struktur der Parasitoidengemeinschaft von Diprion pini (L.) (Hym.; Diprionidae) bei latenten Dichten des Wirtes. $\mathrm{PhD}$ thesis, LudwigMaximilians-Universität, München, 193 pp.

Herz A. \& Heitland W. 1999: Larval parasitism of a forest pest, the common pine sawfly Diprion pini (L.) (Hym., Diprionidae), during an endemic density phase. J. Appl. Entomol. 123: 129-137.

Herz A. \& Heitland W. 2000: First use of pheromones to detect phenology patterns and density relationships of pine sawflies in German forests. Agric. Forest Entomol. 2: 123-129.

Herz A. \& Heitland W. 2003: Impact of cocoon predation and parasitism on endemic populations of the Common Pine Sawfly, Diprion pini (L.) (Hymenoptera, Diprionidae) in different forest types. Agric. Forest Entomol. 5: 35-51.

Hoch G., Zubrik M., Novotny J. \& Schopf A. 2001: The natural enemy complex of the gypsy moth, Lymantria dispar (Lep., Lymantriidae) in different phases of its population dynamics in eastern Austria and Slovakia - a comparative study. $J$. Appl. Entomol. 125: 217-227.

Holling C.S. 1955: The selection by certain mammals of dead, parasitized, and healthy prepupae of the European pine sawfly, Neodiprion sertifer (Geoffr.). Can. J. Zool. 33: 404-419.

Holling C.S. 1958: Sensory stimuli involved in the location and selection of sawfly cocoons by small mammals. Can. J. Zool. 36: 633-653.

KIDD N.A.C. \& JeRVIS M.A. 1997: The impact of parasitoids and predators on forest insect populations. In Watt A.D., Stork N.E. \& Hunter M.D. (eds): Forests and Insects. Chapman \& Hall, London, pp. 49-68.

Larsson S. \& Tenow O. 1984: Areal distribution of a Neodiprion sertifer (Hym., Diprionidae) outbreak on Scots pine as related to stand condition. Holarct. Ecol. 7: 81-90.

Lewis C.N. \& WhitField J.B. 1999: Braconid wasp (Hymenoptera: Braconidae) diversity in forest plots under different silvicultural methods. Environ. Entomol. 28: 986-997.

MagurRan A.E. 1988: Ecological Diversity and its Measurement. Croom Helm, London, 179 pp.
Mills N.J. 1990: Are parasitoids of significance in endemic populations of forest defoliators? Some experimental observations from Gypsy Moth, Lymantria dispar (Lepidoptera: Lymantriidae). In Watt A.D., Leather S.R., Hunter M.D. \& Kidd N.A.C (eds.): Population Dynamics of Forest Insects. Intercept, Andover, pp. 265-274.

Mills N.J. 1994: The structure and complexity of parasitoid communities in relation to biological control. In Hawkins B.A. \& Sheehan W. (eds): Parasitoid Community Ecology. Oxford University Press, Oxford, pp. 397-417.

Nikolskaya M.N. 1952: The Chalcid Fauna of the USSR (Chalcidoidea). Keys to the Fauna of the USSR. Zoological Institute of the Academy of Sciences of the USSR 44, Moscow, USSR. English Translation, 1963, Israel Program for Scientific Translations, Jerusalem, Israel, 593 pp.

OeHLKE J. 1966: Die in europäischen Kiefernbuschhornblattwespen (Diprioninae) parasitierenden Ichneumonidae. Beitr. Entomol. 15: 785-980.

Perkins J.E. 1959: Handbooks for the Identification of British Insects. Vol VII, Part 2 (ai), Ichneumonoidea (part). Royal Entomological Society of London, London, $116 \mathrm{pp}$.

PERKINS J.E. 1960: Handbooks for the Identification of British Insects. Vol VII, Part 2 (aii), Ichneumonoidea (contd.). Royal Entomological Society of London, London, $96 \mathrm{pp}$.

PrICE P.W. 1969: Trail odors: recognition by insects parasitic on cocoons. Science 170: 546-547.

PRICE P.W. 1972: Behavior of the parasitoid Pleolophus basizonus (Hymenoptera: Ichneumonidae) in response to changes in host and parasitoid density. Can. Entomol. 104: 129-140.

PschorN-WaLCHER H. 1964: Zur Kenntnis der gesellig lebenden Kiefernbuschhornblattwespen (Hym., Diprionidae) der Ostalpen. Teil II. Die Parasiten der untersuchten Diprioniden. Pflanzen-Berichte 31: 49-66.

PSCHORN-WALCHER H. 1977: Biological Control of forest insects. Annu. Rev. Entomol. 22: 1-22.

PSCHORN-Walcher H. 1982: Symphyta. Diprionidae. In Schwenke W. (ed.): Die Forstschädlinge Europas. Paul Parey, Hamburg, pp. 66-129.

Quayle D., Regniere J., Cappucino N. \& Dupont A. 2003: Forest composition, host-population density and parasitism of spruce budworm Choristoneura fumiferana eggs by Trichogramma minutum. Entomol. Exp. Appl. 107: 215-227.

RICHARDS O.W. 1956: Handbooks for the Identification of British Insects. Vol VI, Part 1. Hymenoptera: Introduction and Key to Families. Royal Entomological Society of London, London, $94 \mathrm{pp}$.

Roland J., TAYLOR P. \& COOKE B. 1997: Forest structure and the spatial pattern of parasitoid attack. In Watt A.D., Stork N.E. \& Hunter M.D. (eds): Forests and Insects. Chapman \& Hall, London, pp. 97-106.

Russell E.P. 1989: Enemies hypothesis: A review of the effect of vegetational diversity on predatory insects and parasitoids. Environ. Entomol. 18: 590-599.

Ryvkin B.V. 1963: Zur Kenntnis der Biologie von Kiefernblattwespen in Bjelorußland. Beitr. Entomol. 13: 455-464.

RYvkIN B.V. 1969: Die Diprionidae und die Komplexe ihrer natürlichen Feinde. Beitr. Entomol. 19: 595-605.

SCHWENKE W. 1962: Neue Erkenntnisse über Entstehung und Begegnung von Massenvermehrungen an Kiefern- und Fichtennadeln fressender Schadinsekten. Z. Angew. Entomol. 50: $137-142$.

Schwenke W. 1964: Grundzüge der Populationsdynamik und Bekämpfung der Gemeinen Kiefernbuschhorn-Blattwespe, Diprion pini L. Z. Angew. Entomol. 54: 101-107. 
Schwenke W. \& Steger O. 1961: Über Auftreten und Bekämpfung der Kieferbuschhornblattwespen in Nordbayern 1959/60. Allgem. Forstz. 16: 145-147.

Sellenschlo U. \& Wall I. 1984: Die Erzwespen Mitteleuropas. System, Biologie und Bibliographie der Torymidae und Ormyridae. Verlag Erich Bauer, Keltern, 111 pp.

Sharov A.A. 1993: Biology and population dynamics of the common pine sawfly, Diprion pini L., in Russia. In Wagner M. \& Raffa K.F. (eds): Sawfly Life History: Adaptations to Woody Plants. Academic Press, San Diego, pp. 409-429.
SHEEHAN W. 1986: Response by specialist and generalist natural enemies to agroecosystem diversification: a selective review. Environ. Entomol. 15: 456-461.

Simmons G.A., Leonard D.E. \& Chen C.W. 1975: Influence of tree species diversity and composition on parasitism of the spruce budworm, Choristoneura fumiferana (Clem.). Environ. Entomol. 4: 832-836.

Received July 19, 2004; revised and accepted January 19, 2005 